\title{
Evaluation of Seismic Response Modification Factor (R) for Moderate-Rise RC Buildings with Vertical Irregular Configurations
}

Momen Mohamed Ahmed ( $\nabla$ xmomen90@gmail.com )

Assiut University Faculty of Engineering

Mohamed Abdel-Basset Abdo

Assiut University Faculty of Engineering

Waleed Abo El-Wafa Mohamed

Assiut University Faculty of Engineering

\section{Research Article}

Keywords: Pushover nonlinear analysis, Vertical geometric irregularity, Response reduction/modification factor $(R)$

Posted Date: December 9th, 2021

DOI: https://doi.org/10.21203/rs.3.rs-1141410/v1

License: (c) (i) This work is licensed under a Creative Commons Attribution 4.0 International License. Read Full License 


\title{
Evaluation of Seismic Response Modification Factor (R) for
} Moderate-Rise RC Buildings with Vertical Irregular Configurations

\author{
Momen Mohamed. M. Ahmed ${ }^{1}$, Mohamed Abdel-Basset Abdo ${ }^{1}$, \\ Waleed Abo El-Wafa Mohamed ${ }^{1}$
}

\begin{abstract}
Most international design codes consider the nonlinear seismic performance of a structure by the concept of reduction/modification factor (R). Then, an elastic static force-based method can be normally used for seismic design to create earthquake resistant $\mathrm{RC}$ buildings. The response modification factor (R) is sensitive to many aspects such as overall ductility, over-strength, damping, and redundancy levels. Indeed, these factors are severely affected by geometric irregularity of the structural system. So, R-value does not become a constant number for the all types of structures with the same lateral load resisting system, as many standard codes noted. It depends on types, combination, and degrees of geometric vertical irregularity. This research assesses the actual values of $\mathrm{R}$ for regular and familiar vertical irregularity cases in RC buildings with moment-resisting frames (MRF) systems. Also, it takes into account the reduction percent that may occurs in R-value due to these studied vertical irregularities. The vertical irregularity cases, such as set-back and soft story, are essentially needed to be studied greater than ever due to the wide propagation of these types of buildings in Egypt, recently. In addition, the potential analytical methods that may be used to calculate R-value in comparison with Egyptian code's value. Nonlinear static pushover analysis is carried out using ETABS via three-dimensional numerical models. The findings prove that vertical irregular models have poor seismic capacities, in comparison with regular one, due to their sudden change in lateral stiffness than that with regular aspect. So, the response modification factor $(\mathrm{R})$ must be recalculated or even scaled-down before design stage with $15 \%$ and $25 \%$ for single and combined vertical irregularity, respectively. In addition, this investigation derives a vital equation between $R$ values with vertical irregularity ratios in each studied model. This equation shall be a guide for seismic design codes, structural design engineers, and researchers. Accordingly, the response modification factor $\mathrm{R}$ does not become a fixed value regardless vertical irregularity aspects of the buildings, but it has a variable value that depend on their inelastic seismic performance of the lateral load resisting systems.
\end{abstract}

Keywords: Pushover nonlinear analysis, Vertical geometric irregularity, Response reduction/modification factor $(\mathrm{R})$

\& Momen M. M. Ahmed (xmomen90@gmail.com)

${ }^{1}$ Civil Engineering Department, Faculty of Engineering, Assiut University,

Assiut, Egypt 


\section{Introduction}

The main concept of earthquake-resistant design is that a structure should resist strong seismic event without sudden collapse, although it may be subjected to some structural and nonstructural damages. That is achievable because the structure is designed via seismic force which is less than the required due to its inelastic performance and energy dissipation [1-3]. Recent earthquakes indicate that elastic analysis is not an appropriate tool to evaluate the real seismic performance of RC buildings. While, the nonlinear time history analysis (NTHA) is capable to estimate the probable inelastic response of structures, but it is complex and the results are depending on ground motion contents [4]. So, various seismic codes namely Eurocode-8 [5], ECOL-201 [6], ASCE-7 [7], and IS [8] incorporate response reduction, modification, or behavior factor (R), respectively in their seismic analyses. Other performance-based seismic evaluation methods are used instead of NTHA such as nonlinear pushover analysis (NPA). Many approaches are considered NPA to assess the inelastic performance of structures such as displacement coefficient method of FEMA440 [9], capacity spectrum method of ATC-40 [10], N2 method by Fajfar and Fischinger [11], and modal pushover analysis (MPA) [12].

Architectural requirements of building systems often impose the structural systems to have many irregularities in geometry; either horizontal or vertical plane. Vertical irregularities are characterized by vertical discontinuities in the geometry, distribution of mass, rigidity, and strength along the building's elevation. A common two forms of vertical irregularity occurs when there is a reduction in the lateral dimension of the building along its height and change in story's height [13-15]. Such irregularities are known as 'set-back' and soft story irregularities, respectively. Past experiences prove that when vertical irregular buildings locate in an active region, the structural system exhibits poor inelastic performance. So, reliable guidelines are needed for the seismic design regarding these irregularities' effect [16-18].

The main objectives of this paper is to investigate the effects of vertical geometric irregularity on $\mathrm{R}$ values of $\mathrm{RC}$ structures with moment resisting frame (MRF) systems. This is carried out for many vertical irregularity cases such as: set-back and soft story whether individual case or combined cases. The vertical irregularities alter global ductility and over-strength of the buildings. While, plastic hinges early occur at the weak story with combined vertical irregularity aspect. Subsequently, the response reduction factor (R) should be scaled-down to create dependable earthquake resistant buildings. Most of the past researchers focused on finding the ductility component of the response reduction factor for single-degree-of-freedom (SDOF) systems, 2D frames, or even simple regular buildings neglecting geometric irregularities combination effect. In addition, comparisons between methods of R-value calculations and 
code are not included in most previous researches.

\section{Response Modification/Reduction Factor (R)}

The first well-known researches on response reduction factor (R) were conducted by Newmark and Hall [19-21]. The proposed formulas for response modification factor $(\mathrm{R})$ is a function of the vibration period, underneath soil, and inelastic displacement [22]. The $\mathrm{R}$ factor is a principal seismic design tool, which specifies the level of inelasticity in the lateral load resisting system (LLRS) during the seismic event. As per national earthquake hazard reduction program (NEHRP) [23]; the definition of R factor is "factor depends on both damping and ductility inherent in structural systems which are sufficient enough to approach the inelastic lateral deformation of the LLRS". As such, response modification/reduction factor is used to scale-down the elastic response of the structure [24]. During inelastic seismic performance of a structure, R factor shows the capability of structure to dissipate seismic energy, then reduce the seismic forces in earthquake resistant design of the structure $[25,26]$. Also, there are many differences in the response reduction factor's (R) values which specified in different international codes for different types of LLRS. The concept of response reduction factor is the same; to reduce the seismic force and incorporate nonlinearity with the aid of damping, ductility, over-strength, and redundancy aspects [27]. Many researchers in ATC-40 (1996) [10] have investigated formulas for calculating the $\mathrm{R}$-factor. The response modification factor $(\mathrm{R})$ is computed as a product of the following four parameters $[28,29]$ :

$$
\mathrm{R}=\mathrm{R}_{\mu} \times \mathrm{R}_{\Omega} \times \mathrm{R}_{\mathrm{R}} \times \mathrm{R}_{\xi}
$$

Where; $\mathrm{R}_{\mu}$ is the ductility, $\mathrm{R}_{\Omega}$ is the over-strength, $\mathrm{R}_{\mathrm{R}}$ is the redundancy, and $\mathrm{R}_{\xi}$ is the damping factors $[30,31]$. These behavior parameters can be estimated from the nonlinear static pushover (NSP) curve as presented in Figure 1.

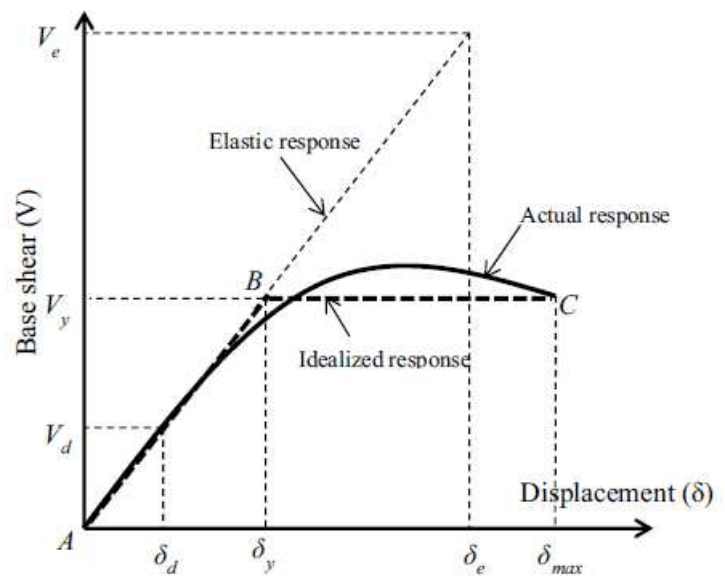


Figure 1 The concept of response modification/reduction factor (R) [32]

Where; Vy and $\delta y$ are yield base shear and yield displacement, respectively. Ve and $\delta$ e are elastic base shear and elastic displacement, respectively. Vd and $\delta \mathrm{d}$ are design base shear and design displacement, respectively.

\subsection{Ductility Factor $(\boldsymbol{R} \mu)$}

Seismic force reduction occurs as a result of ductility $\left(R_{\mu}\right)$ that incorporated in the structural system, reinforcement details of elements, and the period of vibration of the structure. This factor is used to reduce the elastic force demand to the level of yield force of the structure. Ductility is classified according to the nature of deformation being considered, whether it is a strain, curvature, rotation or displacement [33].

$$
R \mu=\frac{V_{e}}{V_{y}}
$$

According to another approach of ductility factor $(\mathrm{R} \mu)$ which presented by Uang [34], R $\mu$ can be determined approximately from the structural ductility ratio $(\mu)$ with the help of the fundamental period of vibration $(\mathrm{T})$ as follows:

$$
\begin{array}{rlrl}
R \mu & =1, & & \text { for } T<0.2 \mathrm{Sec} \\
R \mu=\sqrt{2 \mu-1}, & & \text { for } 0.2 \mathrm{~s}<T<0.5 \mathrm{Sec} \\
R \mu=\mu, & & \text { for } T>0.5 \mathrm{Sec}
\end{array}
$$

The structural ductility ratio $(\mu)$ according to ATC-19 [35] can be defined as:

$$
\mu=\frac{\delta_{\max }}{\delta_{y}}
$$

Mirenda et al. [36] evaluated the ductility factor $(\mathrm{R} \mu)$ with respect of soil coefficient $(\Phi)$ as the following equations:

$$
\mathrm{R} \mu=(\mu-1) /(\Phi+1)
$$

Where $\Phi$ depends on soil conditions and time period.

For rock soil,

$$
\Phi=1+\frac{1}{10 T-\mu T}-\frac{1}{2 T} \exp \left(-\frac{3}{2}\left(\ln T-\frac{3}{5}\right)^{2}\right)
$$

For medium soil, 


$$
\Phi=1+\frac{1}{12 T-\mu T}-\frac{2}{5 T} \exp \left(-2\left(\ln T-\frac{1}{5}\right)^{2}\right)
$$

For soft soil,

$$
\Phi=1+\frac{\mathrm{T}_{g}}{3 T}-\frac{3 \mathrm{~T}_{g}}{4 T} \exp \left(-2\left(\ln \frac{T}{\mathrm{~T}_{g}}-\frac{1}{4}\right)^{2}\right)
$$

Where; $\mathrm{T}$, and $\mathrm{T}_{g}$ is the predominant periods of the structure and ground motion, respectively.

\subsection{Over-strength Factor $\left(\mathrm{R}_{\Omega}\right)$}

This factor specifies the ratio between the real seismic force dominating in the structural system and the required force demand. Over-strength factor presents the amount of the residual resistant force in the structural system. The main sources of the structural over-strength results from sequential yielding of critical regions, material over-strength, strain hardening, capacity reduction factors, member size, and nonstructural elements [37-39]. In addition, the overstrength is generated because of load factors in various design load combinations and reduced design strength of materials by factor of safety. The over-strength factor $\left(R_{\Omega}\right)$ can be estimated as the following equation:

$$
R_{\Omega}=\frac{V_{u}}{V_{d}}
$$

Where, $V_{u}$ is the actual ultimate force that will be obtained from the nonlinear pushover analysis, and $V_{d}$ is the design base shear calculated according to the code [40]. As per the pre-mentioned formulation, the over-strength factor is suggested to be a combination of actual over-strength factor $(\Omega 0)$ and redundancy factor $(\mathrm{RR})$ as the following.

$$
\mathrm{R}_{\Omega}=\mathrm{Vu} / \mathrm{Vd}=(\mathrm{Vu}) /(\mathrm{Vy}) \times(\mathrm{Vy}) /(\mathrm{Vd})=\Omega_{\mathrm{o}} \times \mathrm{RR}
$$

Where, $\Omega$ is the actual over-strength ratio of $\mathrm{Vu} / \mathrm{Vy}$ and $\mathrm{R}_{\mathrm{R}}$ is the redundancy factor of $\mathrm{Vy} / \mathrm{Vd}$.

\subsection{Redundancy Factor $\left(R_{R}\right)$}

The local yielding of a certain structural element does not cause the sudden failure of the overall structure. This is because of the excess load in specific elements, which do not reach to a reserve resistance. This is called redundancy. If the failure of a component of a structure leads to sudden failure of the structural system, thus it is termed as non-redundant structure. The redundancy /reliability of any structural system occurs when the system has multiple load paths with correlated characteristics [30, 41]. From past researches, a redundancy factor $R_{R}=1.0$ is used in this study. 


\subsection{Damping Factor $\left(R_{\xi}\right)$}

Damping factor $(\mathrm{R} \xi)$ is used for structures which are provided with additional energy dissipating devices. The damping factor is assumed as 1 for buildings without any devices [42].

\section{Codes' values for Response Modification Factor ( $R$ )}

The response modification factor's symbols and magnitudes for any structural system might be significantly different from one design code to another. For example, in the European code (EC8) [5], this parameter is called the behavior factor (q). The American design codes ASCE-7 [43], international building code (IBC) [44], and Indian standard (IS) [8] present it as a response reduction factor (R). In addition, The Iranian standard[45] and Egyptian code (ECOL201) [6] prescribe it as a response modification factor (R). Table 1 summarizes the response modification factor $(\mathrm{R})$ in most international codes for $\mathrm{RC}$ moment resisting frame system according to its assumed ductility classification.

Table 1 Response modification factor $(R)$ in the international codes

\begin{tabular}{lll}
\hline Code & Structural system & $\begin{array}{c}\text { Response modification } \\
\text { factor (R) }\end{array}$ \\
\hline \multirow{2}{*}{ EC8 (2004) [5] } & Medium ductility class & 3.00 \\
\cline { 2 - 3 } ASCE-7 (2010) [43], & High ductility class & 4.50 \\
\cline { 2 - 3 } IBC (2003) [44] & Ordinary moment-resisting frame & 3.00 \\
\cline { 2 - 3 } NBCC(1994) [46] & Special moment-resisting frame & 5.00 \\
\hline \multirow{2}{*}{ IS (2002) [8] } & Intermediate moment-resisting frame & 8.00 \\
\hline \multirow{2}{*}{ UBC 97 [47] } & Ordinary moment-resisting frame & 3.50 \\
\cline { 2 - 3 } & Special moment-resisting frame & 6.80 \\
\hline \multirow{2}{*}{ ECOL 201 (2012) [6] } & Ordinary moment-resisting frame & 3.00 \\
\cline { 2 - 3 } & Intermediate moment-resisting frame & 5.00 \\
\cline { 2 - 3 } & Special moment-resisting frame & 3.50 \\
\cline { 2 - 3 } & Sufficient ductility & 5.50 \\
\hline
\end{tabular}

\section{Vertical Geometric Irregularity}

The regular configuration is an essential indication to strong seismic performance of the structures. The main aspects affecting the dynamic characteristics of structures are overall geometry, structural systems type, and available load paths [48-50]. The difference in usage of a specific floor with respect to the adjacent floors results in irregular distributions of mass, stiffness, and lateral resistance along the building height. Thus, poor seismic performance may be generated and need to be re-checked or additional structural elements must to be added [51]. The building may have irregular distributions of mass, strength, and stiffness along its elevation. In such cases, it can be said that the 
building has a vertical irregularity. When the center of mass of different stories do not lie along the same vertical line, this results in severe twisting of structures [52], as shown in Figure 2. Hence, overstressed columns will be generated and a special concern is required from the structural design engineers.

Figure 3 illustrates that set-back irregularity creates lateral deformation of tall (flexible) part is larger than that of short (stiff) part. So, the seismic force demand imposed on taller frame is greater than that on shorter stiffer one, because of the participating mass source is different in each part [53]. Figure 4 presents two examples of different failures for vertical irregular buildings with two different vertical irregularity cases. Figure 4 (a) and (b) present failure mechanism of soft story and set-back irregularity cases, respectively. Where, $\mathrm{FY}_{1}$ and $\mathrm{FY}_{2}$ are the seismic force in $\mathrm{Y}$-direction for example of the lower and upper part, respectively. $\mathrm{CM}_{1}$ and $\mathrm{CM}_{2}$ are the center on mass of the lower and upper part, respectively. The (e) is an accidental eccentricity due to set-back.

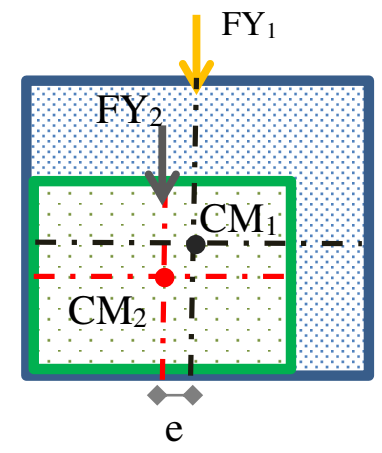

a) Eccentricity in plan

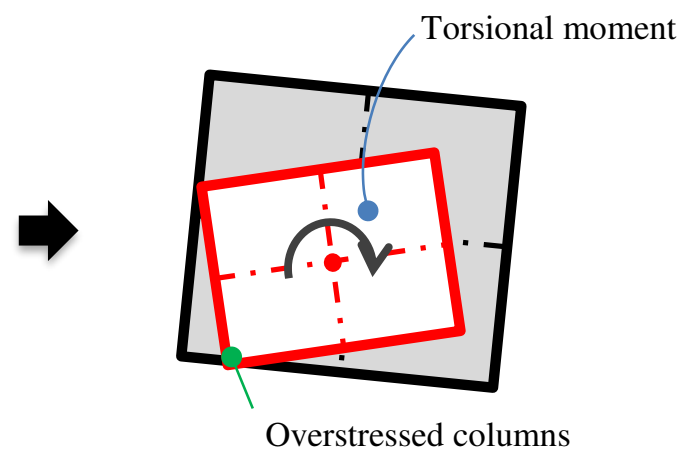

b) Accidental twisting

Figure 2 Torsional moment in vertical irregular buildings

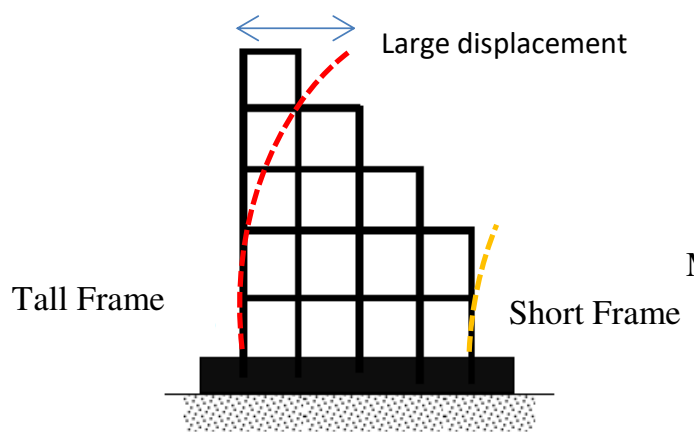

a) Elevation
More mass

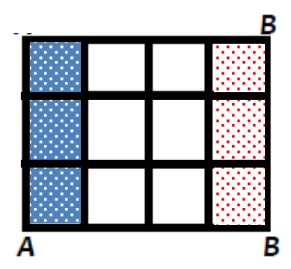

b) Plan

Less mass 
Figure 3 Characteristics of buildings with vertical (mass/set-back) irregularity [53]

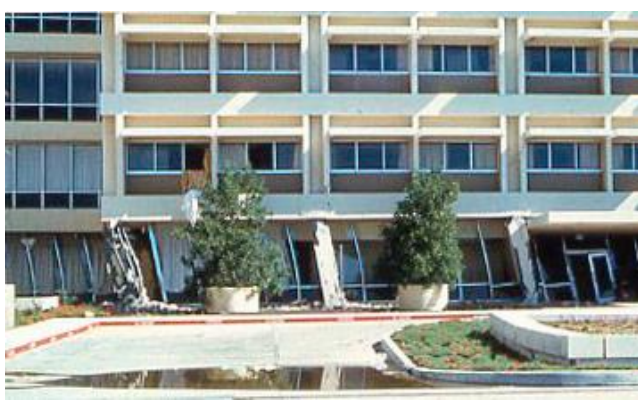

a) Olive view hospital, San Fernando earthquake (1971)

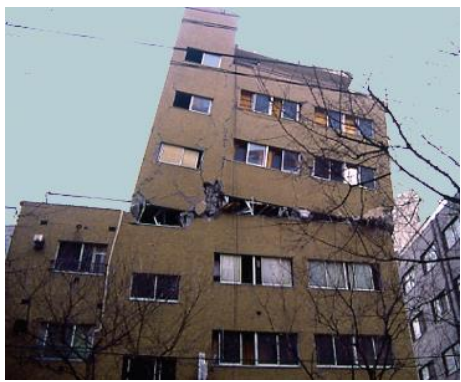

b) Damaged building, Kobe earthquake, Japan (1995)

Figure 4 Examples of vertical irregular buildings' failure [54]

According to ECOL-201 (2012) [6], there are various cases of vertical irregularities. If any of them occurs, the structure can be classified as vertical irregular structure, therefore traditional equivalent static force method cannot be used:

1. Any story has lateral stiffness less than $75 \%$ of the previous one.

2. Change in mass of the story is more than $50 \%$ of that in next the story.

3. For gradual set-back structure, set-back in any story is more than $20 \%$ of that in adjacent story.

4. For one side set-back with $15 \%$ of height, set-back increases with $20 \%$ from the previous story's length.

5. For unsymmetrical set-back, total set-backs exceeds $30 \%$ of the first story length or $10 \%$ of the previous story.

It is unfortunate that no condition in the Egyptian code for response modification factor $\mathrm{R}$ is determined for these vertical irregular cases, while its value depends directly on ductility and over-strength ratios.

\section{Nonlinear Pushover Analysis (NPA)}

Pushover analysis is nonlinear static analysis carried out to determine the capacity of the structure. In this procedure, a predefined lateral load pattern is distributed along the building height. The lateral forces are monotonically increased with lateral displacement till certain level of deformation and plastic hinge modeling as shown in Figure 5. For this nonlinear analysis, plastic hinges have been assigned to all of the structural resistant elements $[55,56]$. The capacity spectrum method (CSM) allows for a graphical comparison between the structural capacity and the seismic demand. Pushover curve represents the lateral resisting capacity while response spectrum curve represents the seismic demand. Building performance level can be determined by target displacement 
using the capacity spectrum method according to ATC-40 [10]. The intersection of the demand spectrum and the capacity spectrum is considered the performance point of the structure. If the base shear at performance point is greater than the design base shear then the structure is safe $[55,57]$.

The force-deformation behavior of the plastic hinge is labelled IO (immediate occupancy), LS (life safety) and CP (collapse prevention). These labels are used to define the acceptance criteria for the hinges. The procedure of classic nonlinear static pushover (NSP) analysis is only applicable to those structures whose response is dominated by the fundamental vibration mode. Therefore, the nonlinear static procedure is not suitable for tall or irregular buildings as in this research, where the higher modes' effects are significant [58]. To overcome the above limitation; Chopra and Goel (2001) [59,60] proposed a practical seismic evaluation procedure called modal pushover analysis (MPA) procedure. It involves the pushover analysis of all significant participated vibration modes of the irregular structure. For each mode, the pushover forces are made proportionally to the corresponding modal inertia forces.
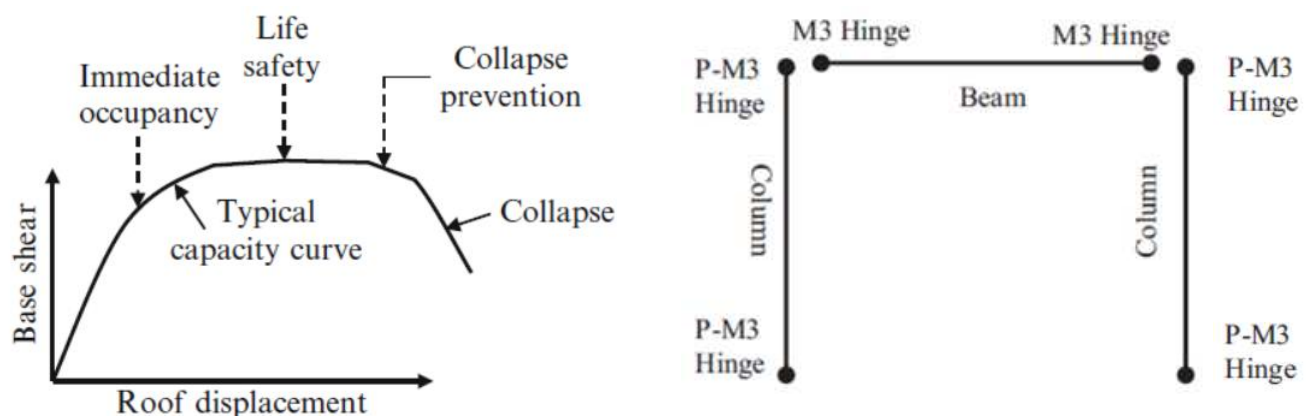

Figure 5 Qualitative capacity curve with performance levels (Limit states) [33] and plastic hinge's location [61]

\section{Description of Studied Buildings}

Three-dimensional models of the studied buildings are constructed using ETABS [62]. Material properties are assumed to be $30 \mathrm{MPa}$ for the concrete compressive strength, 400/600 MPa for the yield/ultimate strength for longitudinal reinforcement, and 240/350 MPa for transverse one. The presented loads are combined, structural members are designed in accordance with the ECP-203 (2017) [63] specifications. The total dimensions for the plan of the building $=25 \times 20 \mathrm{~m}$, consisting of $5 \times 4$ bays of $5 \mathrm{~m}$ for each one, as depicted in Figure 6. The whole height of the structures $=24 \mathrm{~m}$, with 8 typical story of 3 $\mathrm{m}$ height. The buildings are solid-slab type with $0.14 \mathrm{~m}$ slab thickness and $0.25 \times 0.60 \mathrm{~m}$ for beams with $4 \varnothing 16$ for longitudinal rebar (bottom and above supports). The loads considered for designing the frames are given in Table 2. Seismic characteristics of models are presented in Table 3. 
Table 2 Summary of vertical loads on floors

\begin{tabular}{lll}
\hline Dead (own weight) & \multicolumn{2}{l}{ Calculated depending on elements' dimensions } \\
\hline \multirow{2}{*}{ Live load (Hotels' room) } & Typical & $2.50 \mathrm{kN} / \mathrm{m}^{2}$ \\
\cline { 2 - 3 } & Accessible roof & $1.00 \mathrm{kN} / \mathrm{m}^{2}$ \\
\hline \multirow{2}{*}{ Floor covering } & Typical & $1.50 \mathrm{kN} / \mathrm{m}^{2}$ \\
\cline { 2 - 3 } & Roof & $3.00 \mathrm{kN} / \mathrm{m}^{2}$ \\
\hline \multirow{2}{*}{ Partitions of $12 \mathrm{~cm}$ thickness } & Typical only & $5.12 \mathrm{kN} / \mathrm{m}$ \\
\hline
\end{tabular}

Table 3 The seismic characteristics of the studied buildings

\begin{tabular}{llll}
\hline Building location (zone) & $5 \mathrm{~A}$ & Damping ratio $(\zeta)$ & 0.05 \\
\hline PGA & $0.25 \mathrm{~g}$ & Response modification factor $(\mathrm{R})$ & 5.00 \\
\hline Response Curve & I & Soil type $(\mathrm{S})$ & $\mathrm{C}$ \\
\hline Importance factor $(\gamma)$ & 1.20 & Live load \% for mass source $(\Psi)$ & 0.50 \\
\hline
\end{tabular}

Two types of vertical irregularities are considered in this research. Firstly, stiffness irregularity (soft story) as presented in Figure 7, with relative lateral stiffness of the soft story and the following one. Secondly, symmetric and asymmetric setback irregularities are studied with stiffness irregularity as described in Figure 8 Figure 9, respectively with $40 \%$ set-back in the buildings' length. Figure 10 shows the three-dimensional for basic models of buildings under study before vertical irregularities' aspects. The nonlinear static pushover analysis is performed for these pre-mentioned sets of models. Table 4 lists vertical irregularity cases with labels for different models under study. Also, it contains the percent of vertical irregularity percent in each model according to ECOL [6]. In addition, soft story ratios $(\mathrm{SSr})$, setback ratios $(\mathrm{SBr})$, and total vertical irregularity ratio (Vtotal) are calculated using inversed values of their relative stiffness for the adjacent stories. Four models (Group-1) are brought for Ref. (regular), Irr. (1, 2, 3 ) with soft stories in different levels (Ground, third, and Roof). Then, six models (Group-2 and 3) are brought for Irr. T $(1,2,3)$ with combination of symmetric setback with soft story irregularities and Irr. L (1, 2, 3) for combination of asymmetric set-back with soft story irregularities. 


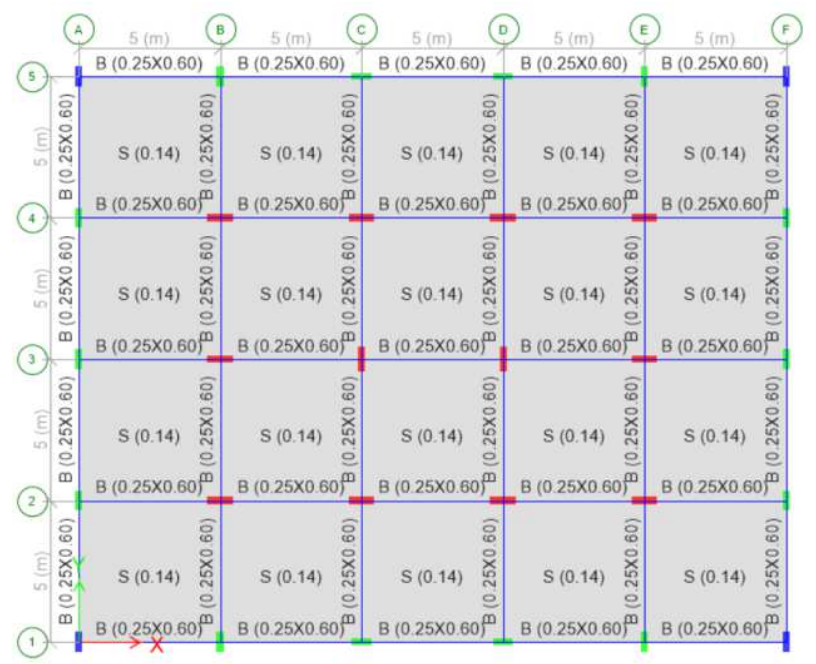

Figure 6 Plan of the studied models

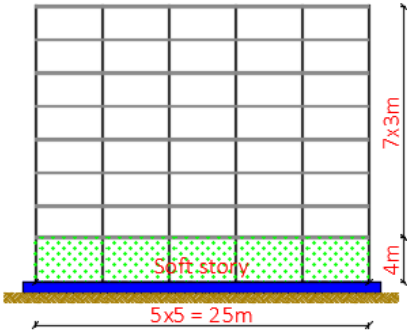

a) Irr.1 model

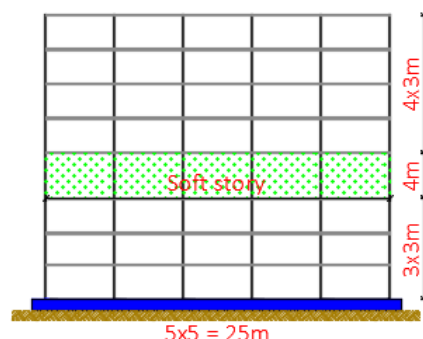

b) Irr. 2 model

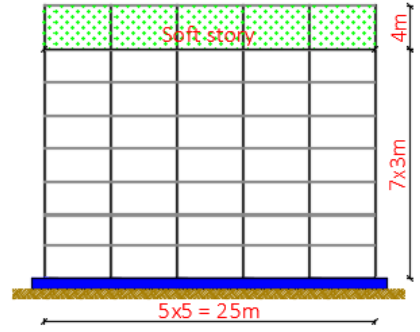

c) Irr.3 model

Figure 7 Vertical irregular models' elevations with soft story (Group-1)

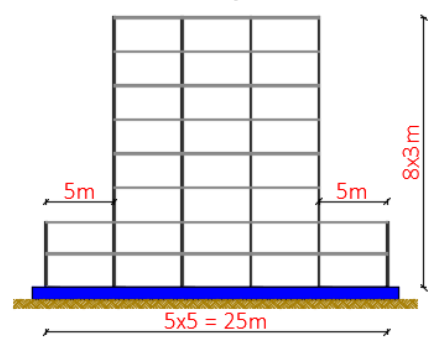

a) Irr. T1 model

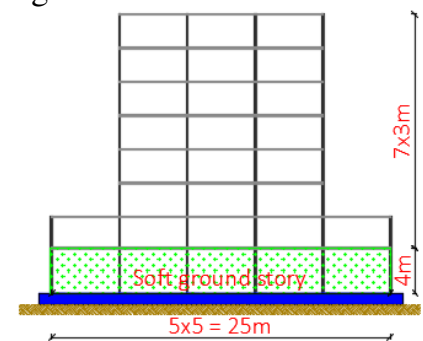

b) Irr. T2 model

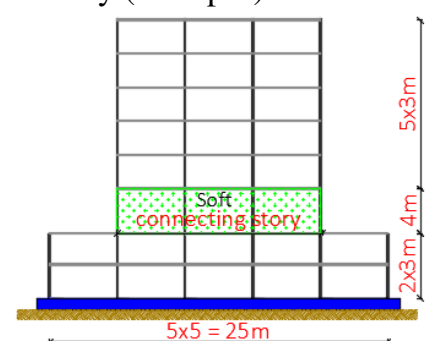

c) Irr. T3 model

Figure 8 Vertical irregular models' elevations with combination of soft story and symmetric set-back (Group-2) 


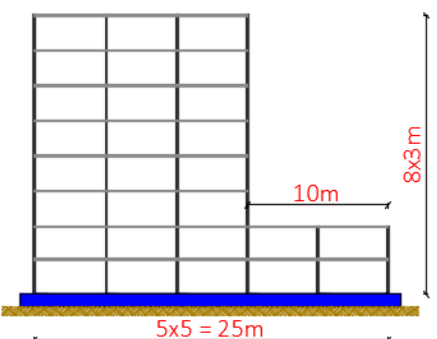

a) Irr. L1 model

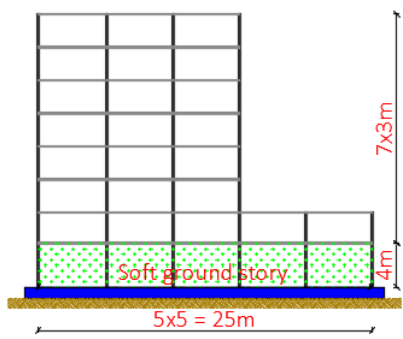

b) Irr. L2 model

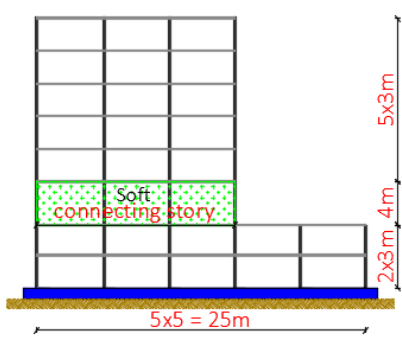

c) Irr. L3 model

Figure 9 Vertical irregular models' elevations with combination of soft story and asymmetric set-back (Group-3)

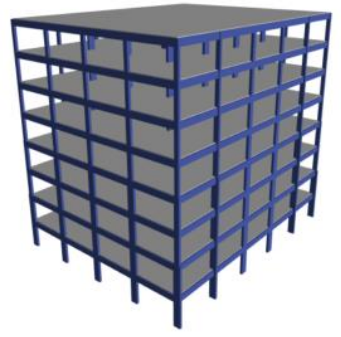

a) Ref. model

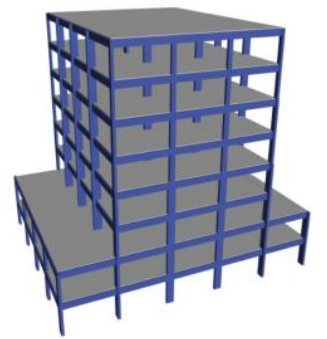

b) Irr. T model

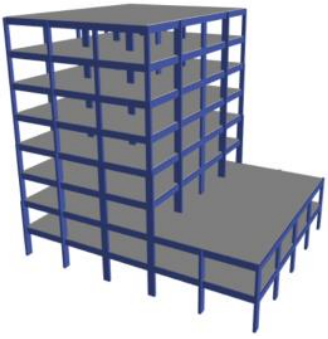

c) Irr. L model

Figure 10 Three-dimensional models for basic buildings under study

Table 4 Vertical irregularities' cases and percentages due to ECOL-2012 [6] for models

\begin{tabular}{|c|c|c|c|c|c|c|c|}
\hline \multicolumn{2}{|c|}{ Models } & \multirow{2}{*}{$\begin{array}{l}\text { Vertical } \\
\text { irregularities' cases }\end{array}$} & \multicolumn{2}{|c|}{ Soft story ratio } & \multicolumn{2}{|c|}{ Set-back ratio } & \multirow{2}{*}{$\begin{array}{c}\begin{array}{c}\text { Total } \\
\text { Vertical } \\
\text { irregularity } \\
\text { (Vtotal) }\end{array} \\
0\end{array}$} \\
\hline \multirow{4}{*}{ 㝘 } & Ref. & & 0 & 0 & 0 & 0 & \\
\hline & Irr.1 & Soft ground story & $42<75 \%$ & 2.38 & 0 & 0 & 2.38 \\
\hline & Irr.2 & Soft third story & $42<75 \%$ & 2.38 & 0 & 0 & 2.38 \\
\hline & Irr.3 & Soft roof story & $42<75 \%$ & 2.38 & 0 & 0 & 2.38 \\
\hline \multirow{3}{*}{ 苍 } & Irr.T1 & Symmetric set-back & $67<75 \%$ & 0 & $40>20 \%$ & 4.63 & 4.63 \\
\hline & Irr.T2 & $\begin{array}{l}\text { Symmetric set-back } \\
\text { with soft ground story }\end{array}$ & $\begin{array}{l}42<75 \% \\
67<75 \%\end{array}$ & 2.38 & $40>20 \%$ & 4.63 & 7.01 \\
\hline & Irr.T3 & $\begin{array}{l}\text { Symmetric set-back } \\
\text { with soft connecting } \\
\text { story }\end{array}$ & $28<75 \%$ & 2.38 & $40>20 \%$ & 4.63 & 7.01 \\
\hline \multirow{3}{*}{ לั: } & Irr.L1 & Asymmetric set-back & $67<75 \%$ & 0 & $40>30 \%$ & 4.63 & 4.63 \\
\hline & Irr.L2 & $\begin{array}{l}\text { Asymmetric set-back } \\
\text { with soft ground story }\end{array}$ & $\begin{array}{l}42<75 \% \\
67<75 \%\end{array}$ & 2.38 & $40>30 \%$ & 4.63 & 7.01 \\
\hline & Irr.L3 & $\begin{array}{l}\text { Asymmetric set-back } \\
\text { with soft connecting } \\
\text { story }\end{array}$ & $28<75 \%$ & 2.38 & $40>30 \%$ & 4.63 & 7.01 \\
\hline
\end{tabular}




\section{$7 \quad$ Results and Discussion}

\subsection{Capacity Curve}

The capacity curves demonstrate the impact of vertical geometric irregularity on seismic capacity of studied numerical models. Then, how ductility and overstrength capabilities of the models will be deteriorated. The maximum capacity curves are plotted for each model in global $\mathrm{x}$ and $\mathrm{y}$ directions as presented in Figure 11 (a-f). Figure 11 (a, and b) plots the capacity curves of the Ref. and Irr. $(1,2,3)$ models (Group-1) in the $\mathrm{x}$ and $\mathrm{y}$ directions, respectively. It is shown that soft ground story of Irr. 1 provides minimum lateral displacement and base shear capability with around $10 \%$ and $30 \%$, respectively. Figure 11 (c-f) exhibits the capacity curves for inverted $\mathrm{T}$ and $\mathrm{L}$ models. It is clear that combination of set-back and soft story irregularity reduces the target displacement and base shear with $20 \%$ and $40 \%$, respectively. The connecting soft story model is the worst case in comparison with the ground soft story one for L models. There are severe differences between the capacity curves for the studied regular and irregular models due to sudden change in stiffness between adjacent stories. In spite of that, most of the standard design codes use the same value of the response reduction factor $(\mathrm{R})$ for the same structural system regardless obvious variation in inelastic seismic performance.

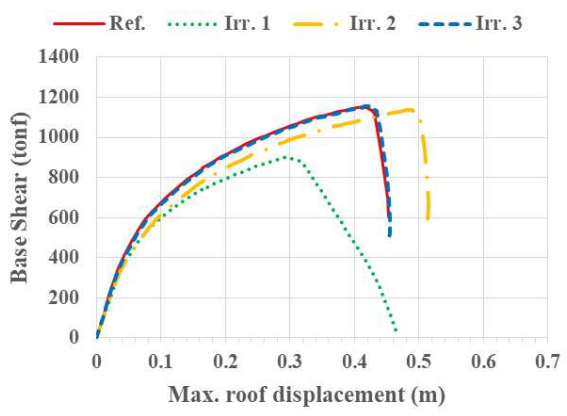

a) X-direction

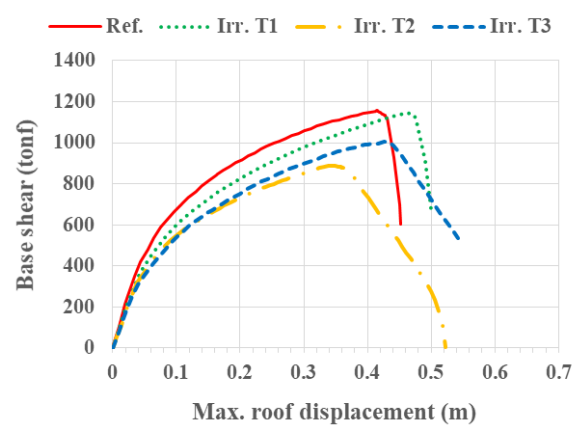

c) X-direction

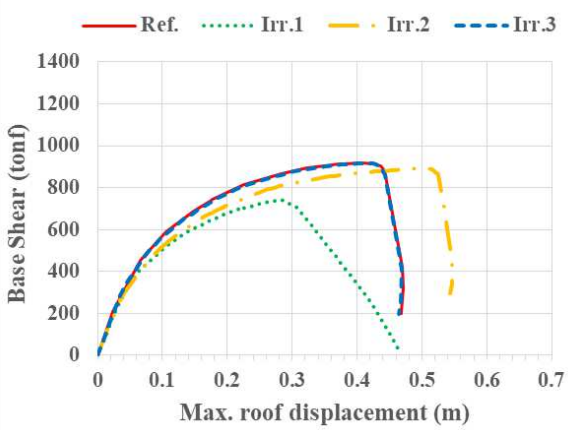

b) Y-direction

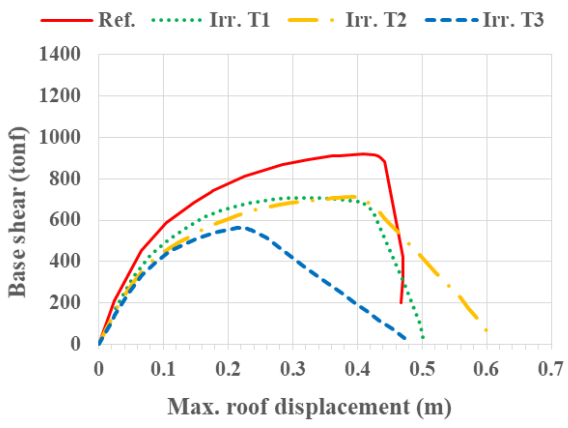

d) Y-direction 


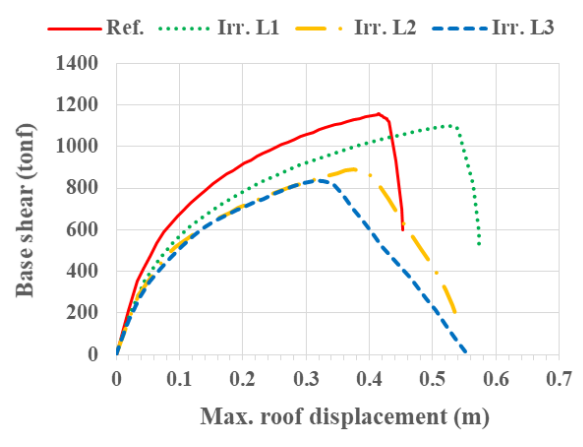

e) X-direction

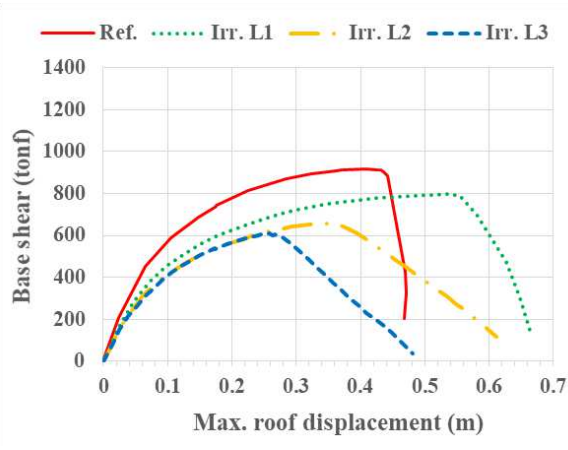

f) Y-direction

Figure 11 Capacity curve results of studied models

\subsection{Ductility Ratio}

Figure 12 (a, b, and c) show the obvious variation in the ductility ratios, $\mu$, with vertical irregularity for all the measured models. It is observed that the ductility factors for the soft ground story buildings are lower than reference/regular one by $15-25 \%$. In cases of buildings Irr. $T(1,2,3)$ and Irr. $\mathrm{L}(1,2,3)$, it is observed that the ductility factor for Ref. model building exceeded by over $14-27 \%$ and $18-25 \%$ for Irr. T and Irr. L, respectively. Irregular buildings $\mathrm{T}$ and $\mathrm{L}$ with soft connecting story have more ductility than those buildings with soft ground story.

\subsection{Over-Strength Ratio}

Figure $13(\mathbf{a}, \mathbf{b}$, and $\mathbf{c})$ show the variance of over-strength ratios values with irregular vertical configurations of buildings. It is seen that the irregular models show lower over-strength values in comparison with the regular ones. Where, over-strength factor of the regular Ref. model exceeds by over $20 \%$ than irregular models. The soft ground story is the worst case of studied vertical irregularity cases for Irr. L with $10 \%$ and $30 \%$ reduction in overstrength value compared with models without soft ground story irregularity and regular model (Ref.), respectively.

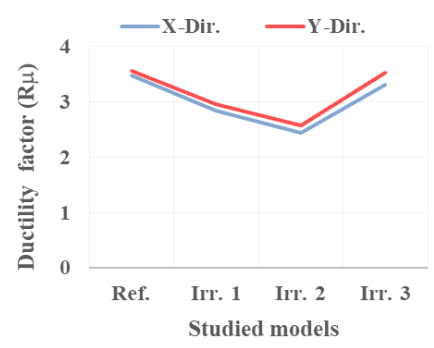

a) Irr. models

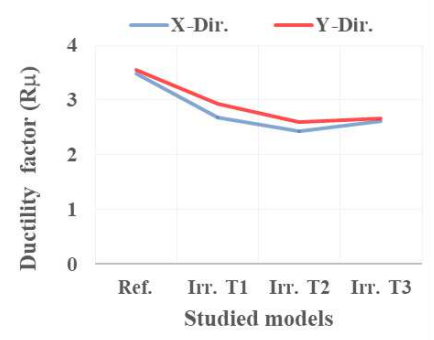

b) Irr. T models

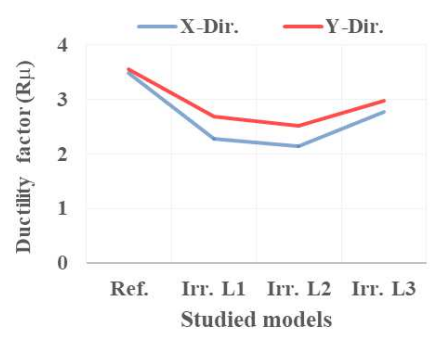

c) Irr. L models

Figure 12 Ductility factor $(\mu)$ for studied models 


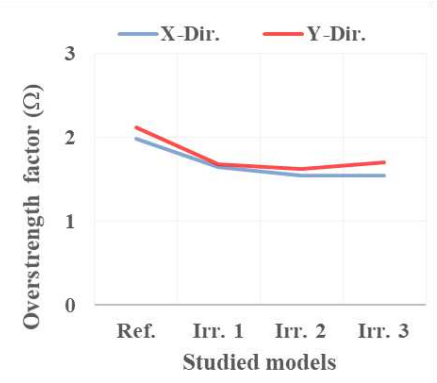

a) Irr. models

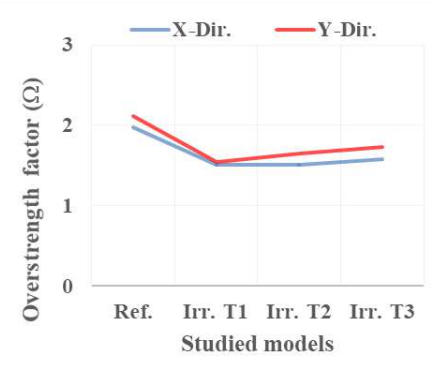

b) Irr. T models

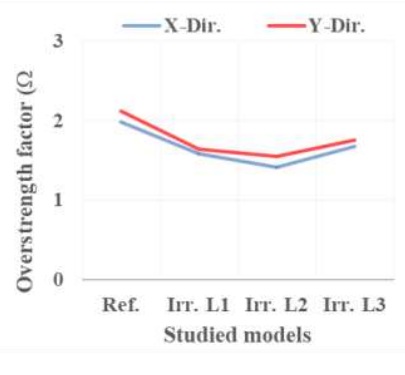

c) Irr. L models

Figure 13 Over-strength factor $(\Omega)$ for studied models

\subsection{Response Reduction Factor $(R)$}

The response reduction factor $(\mathrm{R})$ has been calculated for all three groups of vertical irregularity via Mirenda et al. [36] and Newmark and Hall [20] equations, in which response reduction factors $(\mathrm{R})$ are sufficient for most design codes. Figure $14(\mathbf{a}, \mathbf{b}$, and $\mathbf{c})$ and Figure $15(\mathbf{a}, \mathbf{b}$, and $\mathbf{c})$ present the variation in $\mathrm{R}$ value for different studied models. Where, in case of combination of setback and soft story irregularity, response reduction factor (R) becomes less value for less ductility and over-strength aspects with $40 \%$. It decreases nearly with $30 \%$ for models with soft stories only. Mirenda equations give overestimated values for response reduction factor than Newmark, which become more realistic values for bare moment resisting frames. Eurocode-8 (2004) [5] states that for vertical irregular buildings, the response behavior factor $(\mathrm{R})$ shall be reduced by $20 \%$ as impact of these irregular configurations. Besides, ASCE (2010) [43] prevents these types of buildings with extreme vertical irregularity to be constructed in active seismic zones (E and F). For Egyptian Code ECOL 201-2012 [6], there are no clear provisions for these types of structures according to $\mathrm{R}$ value, while the structural system only is the dominating term regardless its configurations.

Figure 16 (a, b, c, and D) illustrate percentage of reduction in response modification factor $(\mathrm{R})$ for models under study according to ECOL code's value that equals to 5 for moment resisting frame with limited ductility system. It is shown that Irr. L2 model with combination of asymmetric set-back and ground soft story has the worst value of $\mathrm{R}$ with $32 \%$ reduction in comparison with Ref. model. Most of reduction percentages in $\mathrm{R}$ for the vertical irregular models via Newmark equation are nearly corresponding to $20 \%$ reduction that approved via Eurocode as a precautionary step due to geometric irregularity. The differences in R values via Newmark and Mirenda are between 15 to $25 \%$ for models under study either in $\mathrm{X}$ or $\mathrm{Y}$ directions. In spite of that, both Newmark and Mirenda equations are overestimated for Ref. model in $\mathrm{R}$ value's calculation with 15 and $30 \%$, respectively. 
Figure 17 presents the relationship between the response reduction factor for Newmark and Mirenda with the vertical irregularity ratios as shown previously in Table 4. It is clear that vertical irregularity changes any value of $\mathrm{R}$ factor with polynomial relationship as list in equations from 13 to 16 with correlation factor equals to 0.75 . These equations and charts can be used from seismic design codes as a guide to calculate $\mathrm{R}$ value before design stage. Also, Both Newmark and Mirenda have a significant trend with Vt ratios as a vertical irregularity indicator.

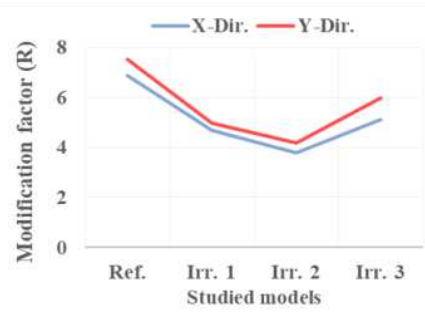

a) Irr. models

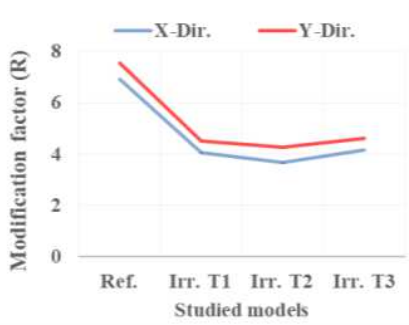

b) Irr. $\mathrm{T}$ models

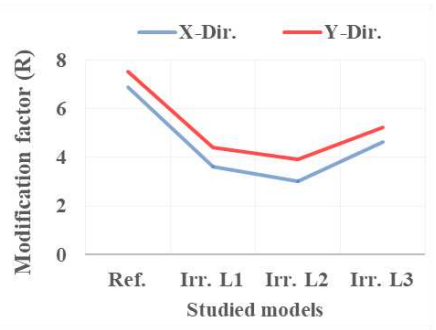

c) Irr. L models

Figure 14 Resonse reduction Factor (R) via Mirenda et al. [36]

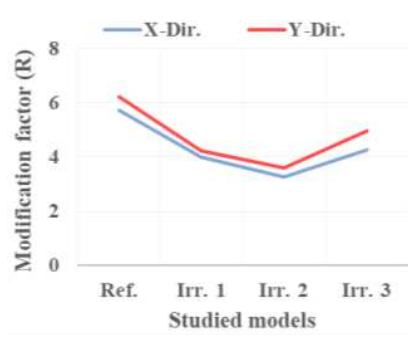

a) Irr. models

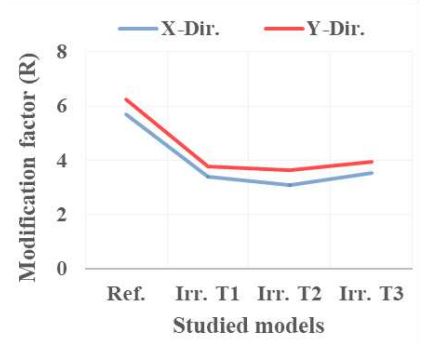

b) Irr. $\mathrm{T}$ models

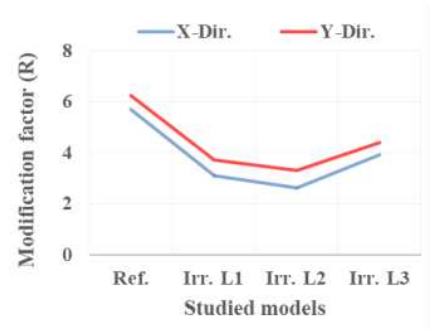

c) Irr. L models

Figure 15 Resonse reduction Factor (R) via Newmark and Hall [20]

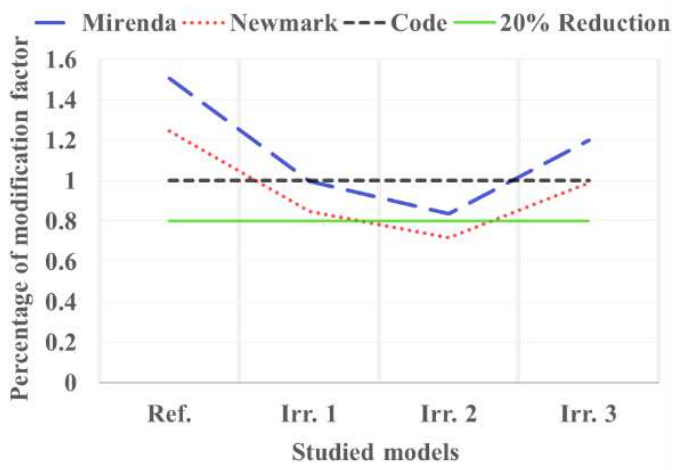

a) X-direction for soft story models

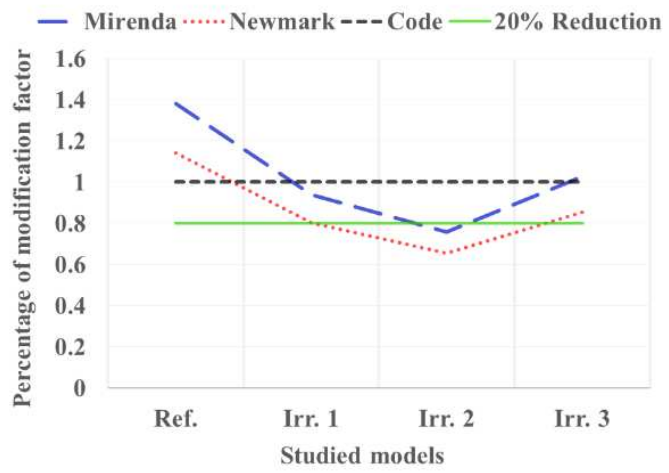

b) Y-direction for soft story models 


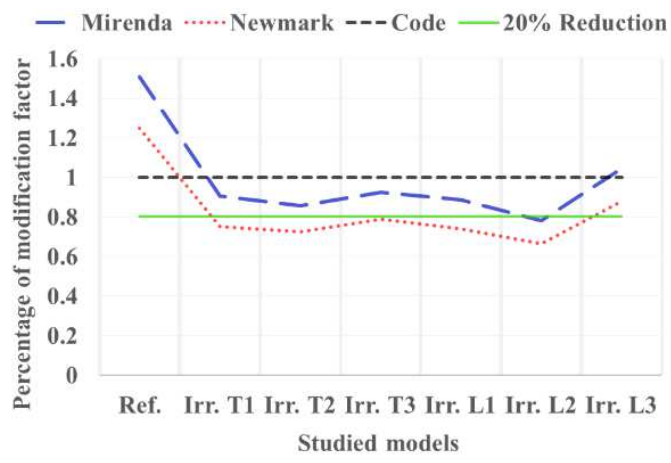

c) X-direction for set-back models

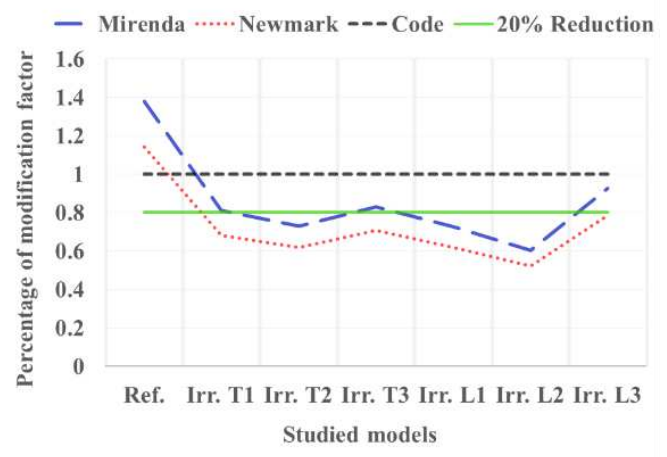

d) Y-direction for set-back models

Figure 16 Percentage of convergence in response modification factor $(\mathrm{R})$ relative to value $(R=5)$ of ECOL code [6]

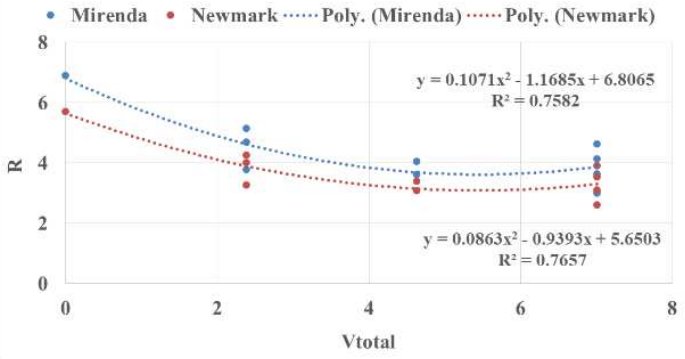

a) X-direction

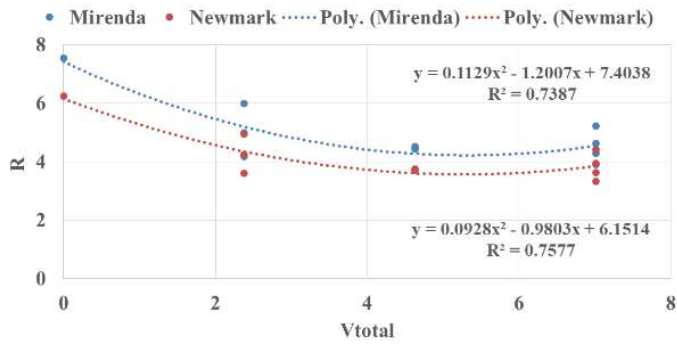

b) Y-direction

Figure 17 Relationship between reduction factor $(\mathrm{R})$ and Vertical irregularity ratios

- For Newmark equation:

$$
\begin{aligned}
& \mathrm{R}=0.086(\mathrm{Vt})^{2}+0.939(\mathrm{Vt})+5.65, \text { for } \mathrm{X} \text {-direction } \\
& \mathrm{R}=0.093(\mathrm{Vt})^{2}+0.980(\mathrm{Vt})+6.15, \text { for } \mathrm{Y} \text {-direction }
\end{aligned}
$$

- For Mirenda equation:

$$
\begin{aligned}
& \mathrm{R}=0.107(\mathrm{Vt})^{2}+1.168(\mathrm{Vt})+6.80, \text { for } \mathrm{X} \text {-direction } \\
& \mathrm{R}=0.113(\mathrm{Vt})^{2}+1.200(\mathrm{Vt})+7.40, \text { for } \mathrm{Y} \text {-direction }
\end{aligned}
$$

\section{Conclusions}

The objective of this study is to identify an appropriate evaluation for response reduction factor $(\mathrm{R})$ of vertical irregular $\mathrm{RC}$ moment resisting frame buildings. From the illustrated results, it can be concluded that many variations occur as a result of vertical irregular configurations. While most of international building codes provide many criteria to classify the vertical irregular structures. But without any specifications about their effect are mentioned on the $\mathrm{R}$ value. 
Whereas, it is considered the main factor in equivalent elastic seismic force calculation. Soft story and set-back irregular buildings are leading to unsymmetrical stiffness and mass distributions. So, their reduction factors (R) need to be scaled-down through modal nonlinear static pushover analysis. Based on the obtained results, the following conclusions can be drawn for the studied models:

1) Vertical irregular buildings suffer from less top displacement and base shear capacity with $10 \%$ and $30 \%$, respectively for soft story irregular buildings compared with regular one. Moreover, about 20\% and $40 \%$ reductions occur in top displacement and base shear capacity, respectively, for buildings with combined set-back and soft story vertical irregularities.

2) The ductility and over-strength ratios are sensitive to vertical irregular configurations with $15 \%$ and $20 \%$ for building with soft story and combination of soft story and set-back irregularity, respectively.

3) The seismic force reduction using $\mathrm{R}$ factor become highly misleading value for vertical irregular buildings. Indeed, the calculated $R$ value is reduced by $20-40 \%$ due to obvious defect in overall ductility and overstrength.

4) Newmark equation has more reliable approach to determine response modification factor (R) than Mirenda equation. While, both of them boost the reduction percent of $20 \%$ for $\mathrm{R}$ value of the vertical geometric irregular structures.

5) The seismic design codes need to be updated through additional precautions for buildings with vertical irregular configurations in case of one type of irregularity occurred or combination of some of them.

6) The response modification factor (R) in ECOL-201 2012 [6] needs to be scaled-down with sufficient percent as EC-8 [5] for vertical irregular buildings, especially for combined ones as T1, T2, L2, and L3 models.

7) There is a significant relationship between the response reduction factor (R) and vertical irregularity percentage (Vtotal) with correlation factor equals to 0.75 . These equations may be vital guide for structural design engineers and researchers.

According to the above results, vertical irregularities in $\mathrm{RC}$ buildings have a significant voice to alter inherent properties of inelastic seismic performance such as ductility, over-strength. So, the response modification factor $\mathrm{R}$ does not become a fixed value regardless vertical irregularity aspects of the buildings.

\section{References}

1. Samar A. Barakat, Abdallah I. Husein Malkawi, Anis S. Al-Shatnawi (1997), A Step Towards Evaluation of the Seismic Response Reduction Factor in Multistorey Reinforced Concrete Frames. "Kluwer Academic Publishers": pp. 65-80. 
2. P. Pravin Venkat Rao, L. M. Gupta (2016), Effect of Seismic Zone and Story Height on Response Reduction Factor for SMRF Designed According to IS 1893(Part-1):2002. "J. Inst. Eng. India Ser. A".

3. Apoorva, Sushma C K (2020), Compresive Study of Different Vertically Irregular High Rise Buildings in High Seismic Zone. "International Research Journal of Engineering and Technology (IRJET)". 7(11): pp. 750-753.

4. Mohsen Gerami, Navid Siahpolo, Reza Vahdani (2017), Effects of higher modes and MDOF on strength reduction factor of elastoplastic structures under far and near-fault ground motions. "Ain Shams Engineering Journal": pp. 127-143.

5. EC-8 (2004), Eurocode 8 - Design of Structures for Earthquake Resistance. Part 1: General Rules, Seismic actions and rules for buildings. "European Committee for Standardization, EN 1998-1", Brussels, Belgium".

6. ECOL-201 (2012), Egyptian code for calculating loads and forces in structural work and masonry. "Housing and Building National Research Center, Ministry of Housing, Utilities and Urban Planning, Cairo, Egypt, 230 p.".

7. ASCE10-41 (2014), Seismic Evaluation and Retrofit of Existing Buildings. "American Society of Civil Engineers".

8. IS-1893 (2002), Indian Standard Criteria for Earthquake Resistant Design of Structures. "Bureau of Indian Standards (BIS), New Delhi".

9. FEMA-440 (2005), Improvement of Nonlinear Static Seismic Analysis Procedures. "Federal Emergency Management Agency, Washington, DC".

10. ATC-40 (1996), Seismic Evaluation and Retrofit of Concrete Buildings. "Applied Technology Council, 346 p.".

11. Fajfar P., Fischinger M. (1988), N2 - A Method for Non-linear Seismic Analysis of Regular Structures. "Proc. 9th World Conf. on Earthquake Engineering, Tokyo/Kyoto". 5: pp. 111-116.

12. Ashwini.K.C and Y. M. Manjunath (2017), Comparative Study of Pushover Analysis on RCC Structures. "International Journal of Engineering Research \& Technology (IJERT)". 6(7): pp. 71-79.

13. M Nishanth, J Visuvasam, J Simon and J S Packiaraj (2017), Assessment of Seismic Response Reduction Factor for Moment Resisting RC Frames. "Structural and Geotechnical Engineering Department, School of Civil and Chemical Engineering, VIT University, Vellore, India".

14. Seranaj, Agim, and Mihail Garevski (2018), The Required Ductility Reduction of Soft Storey Buildings Through Application of Base Isolation. "Res. Eng. Struct. Mat.". 4(1): pp. 49-60.

15. Mabood A, Zameerruddin M, Shimpale PM (2021), Performance-based Seismic Evaluation of Vertically Irregular Moment Resisting Reinforced 
Concrete Frames using Nonlinear Statics Analysis. "International Journal of Civil Engineering". 8(6): pp. 8-19.

16. V. Anagnwstopoulou, C. Zeris, C. Karayannis (2012), Evaluation of the q Factor of Irregular RC Buildings Designed According to EC8. "15th World Conference on Earthquake Engineering, WCEE".

17. Devesh P. Soni, Bharat B. Mistry (2006), Qualitative Review of Seismic Response of Vertically Irregular Building Frames. "ISET Journal of Earthquake Technology". 43(04): pp. 121-132.

18. Dinh Van Thuat, Ho Viet Chuong, Bach Duong (2020), Relationship of

Strength Reduction Factor and Maximum Ductility Factor for Seismic Design of One-Storey Industrial Steel Frames. "Asian Journal of Civil Engineering". 21: pp. 841-856.

19. M. ESER, C. AYDEMIR, I. EKIZ (2011), Effects of Soil Structure Interaction on Strength Reduction Factors. "The Twelfth East AsiaPacific Conference on Structural Engineering and Construction, Procedia Engineering". 14: pp. 1696-1704.

20. Newmark NM, Hall WJ (1973), Seismic Design Criteria for Nuclear Reactor Facilities. "Building Research Series No. 46, National Bureau of Standards, US Department of Commerce, Washington, DC". 209(36).

21. Suman Devkota, Vijay Kumar (2020), Response Reduction Factor for SMRF 3D Frame Buildings on Sloppy Ground. "International Journal of Innovative Technology and Exploring Engineering (IJITEE)". 9(4): pp. 2085-2092.

22. Aly K, Antony Balan (2016), Evaluation on Definition of Strength Reduction Factor for Soil Structure Interaction of Multistoried Buildings. "International Journal of Engineering Research". 05(03): pp. 514-519.

23. NEHRP (2018), The National Earthquake Hazards Reduction Program: Issues in Brief. "Congressional Research Service, https://crsreports.congress.gov".

24. Borzi, B. and Elnashai, A.S. (2000), Refined Force Reduction Factors for Seismic Design. "Engineering Structures". 22.

25. Nirav Patel, Prutha Vyas (2017), Evaluation Of Response Modification Factor For Moment Resisting Frames. "International Conference on Research and Innovations in Science, Engineering \&Technology. Selected papers in Civil Engineering". 1: pp. 118\{123.

26. Behnoud Ganjavi, Hong Hao (2014), Strength Reduction Factor for MDOF Soil-Structure Systems. "The Structural Design of Tall and Special Buildings, Wiley Online Library". 23: pp. 161-180.

27. Ruhullah Amiri, T. N. Patel (2018), Assessment of Seismic Response Reduction Factor According to Redundancy of RC Buildings. "IJSRSET". 04(04): pp. 292-299.

28. Ahmed Hossameldin Hanafy, ohammed Darwish, Moustafa Baraka (2018), Egyptian Code Seismic Load Design Provisions for Moment Resisting Frames. "Springer International Publishing". 8. 
29. Amira Elyamany Mohamed, Walid A Attia, Wael M. El-Degwy (2019), Seismic Response Modification Factorof Reinforced Concrete Frames Based on Pushover Analysis. "Journal of Architectural Environment \& Structural Engineering Research". 02(02): pp. 30-38.

30. Tia Toby, Ajesh K. Kottuppillil (2015), Evaluation of Response Reduction Factor using Nonlinear Analysis. "International Journal for Innovative Research in Science \& Technology (IJIRST)". 02(06): pp. 9398.

31. Hayri Baytan Ozmen, Mehmet Inel (2018), Strength Reduction Factors for Existing Mid-Rise RC Buildings for Different Performance Levels. "Res. Eng. Struct. Mat.". 04(04): pp. 241-255.

32. Hemchandra Chaulagain, Hugo Rodrigues, Enrico Spacone, Ramesh Guragain, Radhakrishna Mallik, Humberto Varum (2014), Response Reduction Factor of Irregular RC Buildings in Kathmandu Valley. "Earthquake Engineering and Engineering Vibration". 13(3): pp. 455470.

33. Sharad Manohar, Suhasini Madhekar (2015), Seismic Design of RC Buildings. "Springer Transactions in Civil and Environmental Engineering".

34. CM, Uang (1991), Establishing R (or Rw) and Cd Factors for Building Seismic Provisions. "J Struct Eng ASCE". 117(1): pp. 19-28.

35. ATC-19 (1995), Structural Response Modification Factors. "Applied Technology Council, Redwood City, USA".

36. Eduardo Mirenda, M EERRI, Vitelmo V. Bertero (1994), Evaluation of Strength Reduction Factors for Earthquake-Resistant Design. "Earthquake Spectra". 10(2): pp. 357-379.

37. Kruti Tamboli, J. A. Amin (2015), Evaluation of Response Reduction Factor and Ductility Factor of RC Braced Frame. "Journal of Materials and Engineering Structures". 2: pp. 120-129.

38. Elnashai AS, Mwafy AM (2002), Overstrength and Force Reduction Factors of Multistorey RC Buildings. "Struct Des Tall Build". 11(5): pp. 329-351.

39. Rodrigues H, Arede A, Varum, H., Costa, A. (2012), Comparative Efficiency Analysis of Different Nonlinear Modeling Strategies to Simulate the Biaxial Response of RC Columns. "Earthquake Engineering and Engineering Vibration". 11: pp. 553-566.

40. Rania Al-Ahmar, Mohammad Al-Samara (2015), An Evaluation of the Seismic Response Modification Factor R for RC Special MomentResisting Frame System. "Int. J. Structural Engineering". 06(04): pp. 368387.

41. Apurba Mondal, Siddhartha Ghosh , G.R. Reddy (2010), PerformanceBased Evaluation Of The Response Reduction Factor For Ductile RC Frames. "The 6th PSU-UNS International Conference on Engineering and 
Technology (ICET-2010), Novi Sad, Serbia, May 15- 17, 2010 University of Novi Sad, Faculty of Technical Sciences".

42. Hamdy Abou-Elfath, Emad Elhout (2018), Evaluating the Response Modification Factors of RC Frames Designed with Different Geometric Configurations. "International Journal of Civil Engineering, Springer".

43. ASCE-7 (2010), Minimum Design Loads for Buildings and Other Structures. "American Society of Civil Engineers, 658 p.".

44. IBC (2003), International Building Code. "International Code Council, INC".

45. INSC (2007), Iranian National Seismic Code of Practice for Seismic Resistant Design of Buildings (Standard No. 2800). "Building \& Housing Research Center".

46. NBCC-105 (1994), Seismic Design of Buildings in Nepal. "Government of Nepal, Ministry of Physical Planning and Works, Department of Urban Development and Building Construction".

47. UBC (1997), Uniform building code, Vol. 2: Structural engineering design provisions. "International Conference of Building Officials (ICBO), Whittier, California, 545 p.".

48. Keerthy Peethambaran, Vivek Philip (2015), Seismic Performance Assessment of Multi- Storeyed RC Moment Resisting Frames Based on Plan Aspect Ratio by Pushover Analysis. "International Journal for Innovative Research in Science \& Technology (IJIRST)". 02(05): pp. 3845.

49. Shehata E. Abdel Raheem, Momen M. M. Ahmed, Mohamed M. Ahmed, Aly G. A. Abdel-shafy (2018), Evaluation of Plan Configuration Irregularity Effects on Seismic Response Demands of L-Shaped MRF Buildings. "Bull Earthquake Eng, Springer". 16: pp. 3845-3869.

50. Abdel Raheem Shehata E., Momen M. M. Ahmed, Mohamed M. Ahmed, Aly G. A. Abdel-shafy (2017), Seismic Performance of L-shaped MultiStorey Buildings with Moment-Resisting Frames. "Proceedings of the Institution of Civil Engineers (ICE)": pp. 1-14.

51. Ozmen, Hayri Baytan, Mehmet Inel, and Emrah Meral. (2014), Evaluation of the Main Parameters Affecting Seismic Performance of the RC Buildings. "Sadhana, Indian Academy of Sciences". 39(2): pp. 437450.

52. Bholebhavi Rahul D., Inamdar V. M. (2016), An Evaluation of Seismic Response Reduction Factor for Irregular Structures Using Non Linear Static Analysis. "International Journal of Innovative Research in Science, Engineering and Technology". 05(05): pp. 4710-4721.

53. Murty, CVR, Goswami, Rupen, Vijayanarayanan, AR, Mehta, V (2012), Earthquake Behaviour of Buildings. "Gujarat State Disaster Management Authority, Gandhinagar".

54. FEMA-454 (2006), Designing for Earthquakes, Risk Management Series, A Manual for Architects. "Federal Emermency Management Agency". 
55. Keerthi S., Vivek Philip (2017), Evaluation of Response Reduction Factor Based on Redundancy for High Rise Buildings. "International Research Journal of Engineering and Technology (IRJET)". 05(04): pp. 3161-3165.

56. Waleed Abo El-Wafa Mohamed, Mostafa Abdou Abd El-Naiem (2008), Seismic Evalution and Retrofit of An Asymmetric Reinforced Concrete Flat Slab Building. "Journal of Engineering Sciences, Assiut University". 36(2): pp. 313-335.

57. Waleed, Abo El Wafa Mohamed (2014), Seismic Capacity of RC Hollow Block Slab Building and Retrofitting Systems. "Journal of Engineering Sciences, Assiut University". 4(3): pp. 629-651.

58. Kalkan E., Kunnath S.K. (2004), Method of Modal Combinations for Pushover Analysis of Buildings. "13th World Conference on Earthquake Engineering, Vancouver, Canada": pp. 2713.

59. Chopra A.K., Goel R.K. (2001), A Modal Pushover Analysis Procedure for Estimating Seismic Demands for Buildings: Theory and Preliminary Evaluation. "PEER Report 2001/2003, Pacific Earthquake Engineering Research Center, College of Engineering, University of California, Berkeley.".

60. Chopra A.K., Goel R.K. (2002), A Modal Pushover Analysis Procedure for Estimating Seismic Demands for Buildings. "Earthquake Engineering and Structural Dynamics". 31(3): pp. 561-582.

61. Mohd. Zameeruddin, Keshav K. Sangle (2021), Performance-based Seismic Assessment of Reinforced Concrete Moment Resisting Frame. "Journal of King Saud University - Engineering Sciences". 33: pp. 153165.

62. CSI (2016), ETABS, Integrated Building Design Software, Computers and Structures, Inc., Berkeley, California.

63. ECOP-203 (2018), Egyptian Code of Practice for Design and Construction of Reinforced Concrete Structures, ECPCS-203. "Housing and Building National Research Center, Ministry of Housing, Utilities and Urban Planning, Cairo, Egypt.". 